\title{
A GEOGRAFIA DA ATIVIDADE TURÍSTICA NO TERRITÓRIO FLUMINENSE: UMA RELEITURA
}

\author{
THE GEOGRAPHY OF TOURISM ACTIVITY IN THE FLUMINENSE TERRITORY: A RE-READ
}

\section{RESUMO}

O estado do Rio de Janeiro caracteriza-se como importante recorte espacial em relação ao desenvolvimento do turismo. As atividades relacionadas ao setor extrapolam a Região Metropolitana, encontrando no interior fluminense atrativos capazes de dinamizar economias municipais. Posto isto, estabelecemos como objetivo para analisar a dimensão espacial do turismo no estado do Rio de Janeiro. Para tanto, o artigo divide-se em três partes, onde a primeira evidencia as condicionantes para o desenvolvimento das práticas turísticas nos municípios fluminenses; a segunda parte trata da institucionalização da atividade no estado; por fim, utilizamos a categorização desenvolvida pelo Ministério do Turismo em 2019 para analisar o processo de consolidação do turismo como importante vetor econômico para municípios fluminenses inseridos na categoria A. A metodologia utilizada consiste no levantamento bibliográfico acerca de lazer, do fenômeno turístico e sua institucionalização, bem como do processo de ocupação e desenvolvimento econômico dos municípios fluminenses. Além disso, recorremos a documentos e dados divulgados por órgãos públicos nas escalas federal, estadual e municipal.

Palavras-chave: Dimensão espacial; Turismo; Regionalização; Estado do Rio de Janeiro.

\section{ABSTRACT}

The state of Rio de Janeiro has been characterized as an important spatial clipping in relation to tourism development. Activities related to the sector go beyond the Região Metropolitana, finding in the interior of Rio de Janeiro attractions capable of boosting municipal economies. That said, we establish as the objective to analyze the spatial dimension of tourism in the state of Rio de Janeiro. To this end, the article is divided into three parts, where the first show the conditioning factors for the development of tourist practices in the municipalities of Rio de Janeiro; the second part deals with the institutionalization of activity in the state; finally, we use of the categorization developed by the Ministry of Tourism in 2019 to analyze the process of tourism expansion as an important economic vector for municipalities in Rio de Janeiro. , as well as the process of occupation and economic development of the municipalities of Rio de Janeiro. In addition, we use documents and data disclosed by public agencies at the federal, state and municipal levels.

Keywords: Spatial dimension; Tourism; Regionalization; Rio de Janeiro state.

\section{Nathan da Silva Nunes ${ }^{a}$}

Miguel Angelo Ribeiro ${ }^{a}$

a Universidade do Estado do Rio de Janeiro (UERJ), Rio de Janeiro, RJ, Brasil

DOI: $10.12957 /$ geouerj.2019.48407

Correpondência:mamikisi@gmail.com

Recebido em: 23 set. 2019

Revisado em: 19 out. 2019

Aceito em: 14 dez.2019 


\section{INTRODUÇÃO}

Este artigo tem como objetivo analisar a dimensão espacial do Turismo no Estado do Rio de Janeiro, tendo por base artigo elaborado anteriormente (NUNES e RIBEIRO, 2018) visto que tal atividade tem importância econômica destacada para diversos municípios fluminenses. A seleção do recorte espacial ocorreu em função da observação de características que tornam o referido estado singular, visto que é possível identificar a prática de atividades relacionadas a diversas tipologias turísticas, dentre elas de sol e mar, o ecoturismo, o cultural e outros.

É válido ressaltar que estatísticas recentes apontam para um crescimento mundial dos fluxos relacionados ao turismo, com cerca de 1,3 bilhão de pessoas deslocando-se pelo planeta em 2017 e 1,4 bilhão em 2018.

Neste contexto, podemos pontuar que o estado do Rio de Janeiro caracteriza-se por apresentar enorme diversidade de situações topográficas e climáticas, bem como grande variedade de condições históricoculturais (RIBEIRO, 2003). Isto posto, a atividade turística se reveste de grande importância como fator de interiorização do desenvolvimento econômico e social, considerada atualmente uma expressão das mais autênticas do processo de globalização.

O fenômeno do turismo expande-se em âmbito planetário até as regiões mais remotas, não desconsiderando nenhum território, e neste contexto, o Brasil encontra-se inserido nesta economia globalizada através da referida atividade, quer em decorrência de suas mais diversas paisagens, dentre elas as tropicais, como também em seus diferentes aspectos culturais e históricos, tornando-se na América Latina uma das principais áreas receptoras desses fluxos (RIBEIRO, 2003).

O Brasil recebeu em 2017 e 2018 aproximadamente 6,6 e 6,7 milhões de turistas estrangeiros, respectivamente, e destes, mais de 1,5 milhão (em ambos os anos) tendo como destino o território fluminense, como indicado pelo Ministério do Turismo. Sendo assim, o referido território é uma das unidades federadas que apresenta importância para a promoção do turismo brasileiro, atividade esta que merece destaque no contexto do desenvolvimento econômico de nosso estado.

No contexto nacional, o Rio de Janeiro é o segundo ente federativo quando tratamos do número de viagens a negócio, porém está na liderança quando a motivação do deslocamento é o lazer, destacando-se não apenas a capital, mas alguns municípios do interior, como Armação dos Búzios, Cabo Frio, Angra dos Reis e Paraty.

Na figura 1 estão representadas as oito Regiões de Governo e os 92 municípios que constituem a referida Unidade Federativa e aqueles selecionados para análise. 
Figura. Regiões de Governo do estado do Rio de Janeiro Fonte: Centro Estadual de Estatísticas, Pesquisas e Formação de Servidores Públicos do Rio de Janeiro, 2019.

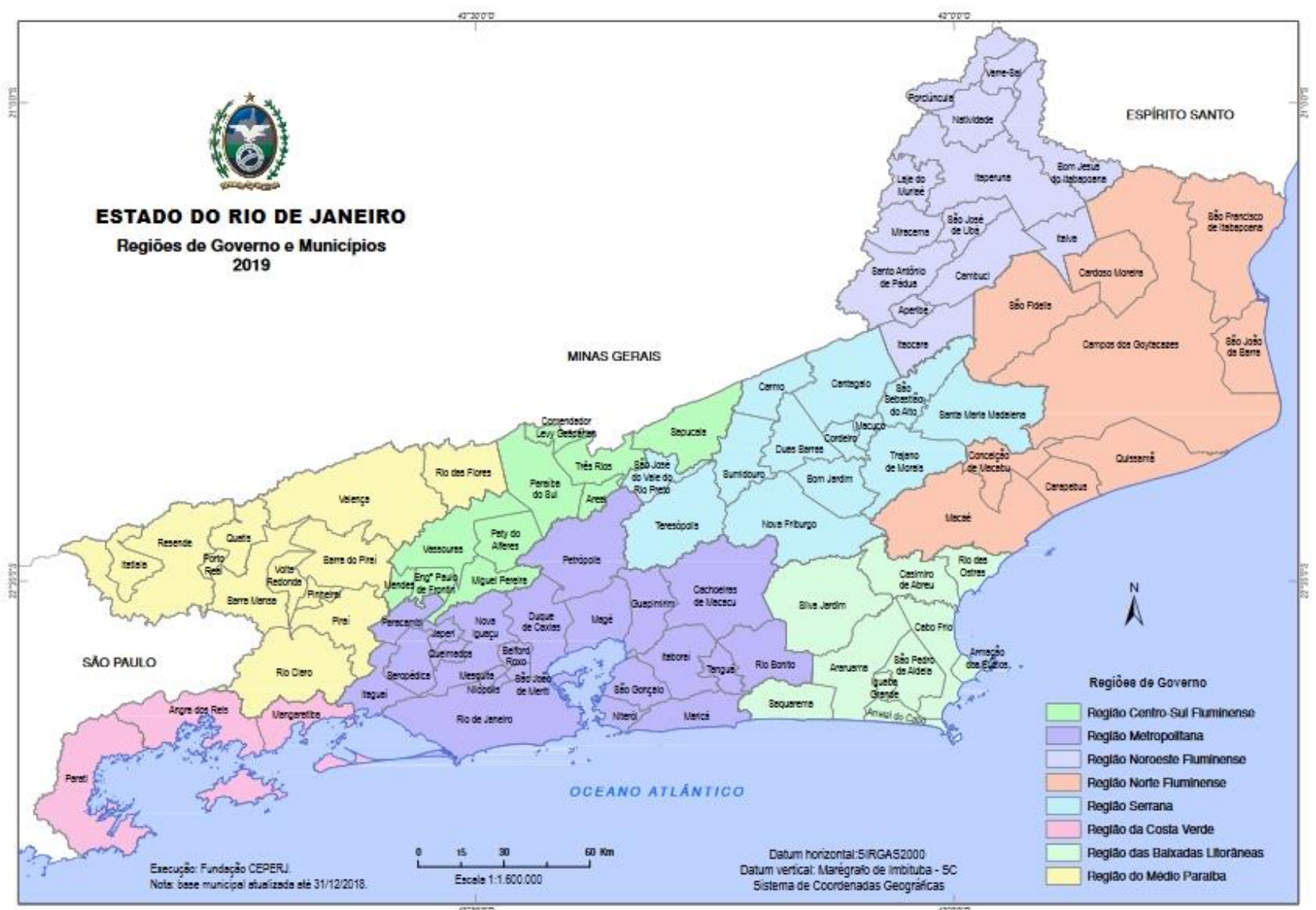

Tais resultados ratificam o papel do estado do Rio de Janeiro como uma das principais unidades receptoras de turistas nacionais e internacionais, apresentando importância para a promoção do turismo brasileiro.

Para que possamos atender os desafios propostos, o artigo encontra-se estruturado em três partes. A primeira envolve as condicionantes para o desenvolvimento das atividades turísticas no território fluminense, destacando-se os elementos físicos ou naturais, o elemento histórico e as atividades econômicas; o papel dos transportes e as políticas de turismo. Na segunda seção procura-se discutir a institucionalização do Turismo no estado, partindo da década de 1960, quando são criadas as primeiras empresas públicas voltadas ao setor, abordando ainda os planos, as tipologias e as classificações oficiais desenvolvidas para os municípios fluminenses. Por fim, na terceira seção o foco será analisar e descrever as atividades turísticas em alguns municípios do estado, sendo selecionados aqueles em que o setor apresenta maior representatividade no contexto nacional, segundo classificações do Ministério do Turismo. 


\section{Condicionantes para o desenvolvimento das práticas turísticas nos municípios fluminenses}

Para que possamos realizar uma análise acerca dos principais aspectos da atividade turística verificados no estado do Rio de Janeiro, é preciso apresentar as condicionantes que viabiliza tal fenômeno. Porém, é necessário em um primeiro momento apresentar concepções e definições acerca de lazer, pois este relacionase intimamente com o turismo.

Para tanto, Menoia (2000) destaca o caráter de oposição entre o conceito de lazer e o trabalho, visto que a redução na carga horária deste último tem propiciado mais tempo livre para o homem, um ser lúdico. Barbosa e Silva (2011), por sua vez, data do período pós-Revolução Industrial o início das discussões a respeito do lazer, sucedendo aquelas que tinham como objeto principal de análise o ócio, o não trabalho. Tais debates estavam inseridos no contexto marxista e sua crítica ao sistema capitalista.

Há uma série de conceituações para o referido termo, considerando em sua maioria a dimensão temporal, a atividade, a função, a importância e a maneira como é usufruído pelo homem (MENOIA, 2000). A partir da concepção do sociólogo francês Dumazedier, Menoia (2000, p.11) apresenta considerações sobre o lazer.

\footnotetext{
Segundo o autor, o lazer completo possui caráter liberatório, de livre escolha; caráter desinteressado, sem fim lucrativo, caráter hedonístico, de satisfação; caráter pessoal, onde as expectativas superam as necessidades. Classifica então o lazer em quatro tipos, conforme o tempo disponível: lazer do fim do dia, do final de semana, do final do ano e do fim da vida.
}

Visando relacionar tal conceito à temática proposta para este artigo, utilizaremos a abordagem de Barbosa (2011, p.4) para associá-lo ao turismo, pois a autora entende que o lazer está vinculado à liberação e prazer, podendo apresentar três funções distintas: que seriam "a do descanso (libera-se da fadiga); do divertimento, recreação e entretenimento (liga-se à fadiga e esta, ao tédio) e do desenvolvimento (desenvolve a personalidade que depende de autonomia do pensamento e da ação cotidiana)".

Após apresentar o lazer a partir do turismo, iniciaremos a análise de tais atividades de forma mais abrangente, destacando em um primeiro momento que não podem ser pensadas sem as bases geográficas e, neste contexto, podemos distinguir três condicionantes que influenciam seu desenvolvimento em território fluminense. Tais condicionantes estão intimamente relacionadas. São elas: a) o elemento físico ou natural; b) o elemento histórico e as atividades econômicas; e c) o papel dos transportes.

\section{O elemento físico ou natural}

O quadro físico fluminense apresenta-se muito diversificado, em contraponto à limitada extensão territorial (CIDE, 1997). Neste sentido, o estado do Rio de Janeiro configura uma sucessão de paisagens, cujo alinhamento segue, aproximadamente, a direção geral SW-NE, dominada pela disposição do relevo, que 
condiciona, em grande parte, a variedade do clima e da cobertura vegetal, entre outros elementos. Sendo assim, distinguem-se como principais unidades físicas: o trecho litorâneo, o conjunto montanhoso e o planalto ondulado até o Vale do Paraíba, como apontou, grosso modo, Ribeiro (2003).

i- $O$ trecho litorâneo, abrange a linha costeira e a região das baixadas, em direção à parte setentrional do estado, constituído por lagoas e cordões litorâneos, com vegetação de restinga. Parte desta área integra a região turística denominada Costa doSol, iniciando-se nos limites da área Metropolitana (município de Maricá) até o município de Rio das Ostras; e a parte meridional, de constituição rochosa e muito recortada em baías e enseadas, prolongando-se até o município de Parati. Nesta unidade física, a modalidade de turismo mais desenvolvida é a do aproveitamento das praias e das práticas náuticas, apesar de atualmente novas modalidades de turismo serem utilizadas, como a histórico-cultural, a rural e o ecoturismo.

ii- O conjunto montanhoso da Serra do Mar, representado pela frente escarpada e seu reverso, atravessando quase todo o estado, com altitudes de até 2000 metros (Serra dos Órgãos), em alguns pontos, é caracterizado por temperaturas mais amenas, quando comparado com as demais unidades físicas, imprimindo características peculiares às diferentes modalidades turísticas. Esta porção é conhecida como Região Serrana.

iii- Por fim, distingue-se o planalto ondulado, que perde altitude até o Vale do Paraíba do Sul, sendo que o rio de mesmo nome representa o traço mais marcante nessa paisagem, cortando o território fluminense de sul para norte, formando uma depressão encaixada entre as escarpas das Serras do Mar e da Mantiqueira, esta exibindo o paredão do Pico das Agulhas Negras, com aproximadamente $2800 \mathrm{~m}$ de altitude, muito aproveitado para diferentes modalidades de turismo.

Esse quadro físico constitui-se em suporte material para a organização econômica e social fluminense, estando diretamente associado ao desenvolvimento da atividade do turismo, exercendo influência na produção de lugares para o consumo.

\section{O elemento histórico e as atividades econômicas}

O elemento histórico e as atividades econômicas são importantes condicionantes para o desenvolvimento da atividade turística. Neste sentido, de modo geral, podemos analisar a ocupação do atual estado do Rio de Janeiro pelos portugueses a partir do século XVI.

O século XVI marca a descoberta da faixa litorânea do Estado, pela expedição em que tomou parte Américo Vespúcio (1501-1502), sendo que em 1503 é instalada uma feitoria na futura cidade de Cabo Frio, enquanto em 1565 é fundada a cidade do Rio de Janeiro. Sendo assim, formas pretéritas criadas no século XVI ainda persistem nestes espaços e são testemunhos importantes para a preservação da memória e da cultura. 
Este século é marcado pela Coroa Portuguesa com a ocupação do litoral, como defesa e conquista da terra (RAHY, 1999), destacando-se a importância do sítio, ou seja, o local no qual estabeleceram-se as futuras cidades, geralmente ocupando a entrada de baías, rios etc, com a presença de inúmeras fortificações, como as encontradas na Baía de Guanabara (RIBEIRO, 2006).

O século XVII vai ser marcado pelas experiências agrícolas vinculadas à produção de cana-de-açúcar e seus engenhos no Norte Fluminense ou mesmo nos arredores da capital. Esta atividade marca a paisagem dessa região até os dias atuais, encontrando-se fazendas dos antigos barões do açúcar e usinas; enquanto na área metropolitana, pelas grandes transformações ocorridas, poucos vestígios foram deixados na paisagem.

No século XVIII, com a descoberta das reservas auríferas das Minas Gerais, a organização do povoamento fluminense vai ser profundamente alterada. A exploração do ouro influencia indiretamente na ocupação do território. Concomitante à exploração aurífera nas Minas Gerais, nos primeiros anos desse século, a cana-de açúcar atinge definitivamente a baixada campista, na porção norte do Estado.

Quanto à atividade aurífera mineira, as cargas do referido metal desciam do planalto das Minas Gerais em lombos de burros, na direção de Parati (Caminho Velho) e eram conduzidos por mar até o Rio de Janeiro (MOTA; LOPEZ, 2016).

O Rio de Janeiro torna-se rapidamente o principal porto e a mais ativa cidade do país, ao mesmo tempo, a atividade aurífera contribui para o aparecimento de vilas - embriões para futuras cidades - que serviam de passagem para o interior, como Vassouras, Paraíba do Sul e Paty do Alferes, entre outras (RAHY, op. cit).

No século XVIII, do ponto de vista histórico e político, merece destaque para a antiga Província do Rio de Janeiro, a transferência da sede do governo colonial de Salvador para o Rio de Janeiro (1763), em decorrência do comércio do ouro das Minas Gerais, além das condições geográficas.

Cumpre lembrar que no período compreendido entre os séculos XVII e XVIII, os portos tiveram importância fundamental na história econômica fluminense, primeiramente com o transporte de cana-deaçúcar, e logo em seguida com o ouro.

O início do século XIX vai ser marcado, primeiramente, pela extinção do ouro das Minas Gerais (decadência da mineração), enquanto a cana-de-açúcar volta a concentrar, mas por pouco tempo, todas as atenções.

Outro fato histórico e político importante para o atual Estado do Rio de Janeiro e mais diretamente para a cidade do Rio de Janeiro, vai ser.a chegada da Corte Portuguesa, em 1808, que afetará a estrutura organizacional da urbe carioca. Em 1834, a cidade do Rio de Janeiro separou-se de sua província e a capital 
imperial foi elevada à condição de Município Neutro, enquanto a cidade de Niterói tornou-se capital da Província Fluminense, em 1835 (RIBEIRO, 2001).

À medida que o Império se consolidava, surgia um novo produto-rei na economia fluminense: o café. Esta nova cultura de base exportadora começa o seu trajeto na cidade do Rio de Janeiro, mais precisamente no Maciço da Carioca, nas encostas de Jacarepaguá, além dos Maciços da Pedra Branca e Mendanha. Foi plantado em várias áreas do território fluminense, embora não tenha obtido o resultado esperado, em decorrência da declividade do terreno e das condições climáticas. Mas a maior expressão cafeeira da antiga província iria ocorrer quando, a partir do Mendanha, a rubiácea atingiu São João Marcos (parte do atual município de Rio Claro), Piraí e Resende, chegando, portanto, ao Vale do Paraíba, em seu trecho médio.

O café, no Médio Paraíba Fluminense, teve seu plantio expandido para várias direções, sendo cultivado ao norte em Entre Rios (atual município de Três Rios), seguindo para Nova Friburgo e Cantagalo, na Região Serrana, terminando sua expansão em Itaocara e São Fidélis, seguindo a direção da Zona da Mata Mineira e do Espírito Santo.

As encostas foram ocupadas com cafezais e o fundo dos vales com as sedes das fazendas e instalações de beneficiamento do produto. Atualmente, muitas destas fazendas, principalmente aquelas localizadas no Médio Paraíba, nos municípios de Vassouras, Valença, Paraíba do Sul, entre outros, estão sendo resgatadas para a atividade turística, a partir de um processo de refuncionalização.

Os elementos históricos na paisagem, muitos deles, fruto das atividades econômicas desenvolvidas em território fluminense, representam importantes marcos no processo de ocupação, e que hoje podem ser resgatados como elementos culturais e da memória de um povo, constituindo-se em vetores das diferentes modalidades de turismo.

Tais elementos históricos tiveram sucesso graças ao papel dos transportes e sua evolução, graças as técnicas que foram sendo desenvolvidas.

\section{O papel dos transportes}

Os transportes são importantes aliados para o desenvolvimento da atividade do turismo. Estes sistemas de engenharia são relevantes no sentido de promoverem a rapidez dos deslocamentos e das comunicações, promovendo a articulação entre áreas emissoras e receptoras de visitantes/turistas.

Para o Estado do Rio de Janeiro, os mesmos tiveram papel preponderante, no tocante a expansão do turismo interno, primeiramente com a difusão das estradas de ferro, à partir de 1854 e impulsionadas com o esplendor da cultura cafeeira, a partir de 1870, e principalmente com o advento das rodovias, iniciadas no final da década de 1940. 
As rodovias tiveram papel vital para a expansão do turismo em território fluminense, concretizando-se, notadamente a partir da década de 1970, com a construção da Ponte Presidente Costa e Silva, ligando as duas principais cidades do Estado, Rio de Janeiro e Niterói; a abertura da BR-101; além da duplicação das rodovias Presidente Dutra (BR-116) e da Washington Luís (BR-040), ligando a capital do Estado, as cidades mineiras de Juiz de Fora e Belo Horizonte.

Com a implantação da BR-101 em território fluminense, além da construção da Ponte Rio-Niterói, concretizada em 1974, a tendência foi haver uma expansão da atividade turística em direção ao litoral sul (Costa Verde) e ao litoral norte (Costa do Sol). Esses são dois grandes vetores de expansão do turismo litorâneo, secundados pela BR-116 (Rodovia Presidente Dutra) que corta a região do Vale do Paraíba.

A duplicação e melhoramento desses eixos de transporte vieram a contribuir de forma positiva para o desenvolvimento da atividade turística em terras fluminenses, principalmente para os municípios localizados externamente à metrópole, tanto os litorâneos, como também os do interior. Tal fato, associado aos outros elementos, como o quadro natural diversificado, e aos condicionantes históricos ensejaram a difusão da atividade turística por alguns municípios fluminenses, tornando-os verdadeiros lugares para o consumo.

Posto isto, no próximo segmento relacionaremos a influência dos elementos apresentados com os tipos de turismo praticados nas Baixadas Litorâneas fluminense, objetivando caracterizar esta atividade a partir das estratégias e políticas adotadas pelo poder público.

Institucionalização turística, tipologia e categorização dos municípios selecionados do estado do Rio de Janeiro

A atividade turística apresenta grande destaque quando tratamos do estado do Rio de Janeiro, muito em função da fama e simbolismo que tem a capital, com pontos turísticos conhecidos mundialmente, como o Pão de Açúcar, o Cristo Redentor, a praia de Copacabana, o estádio do Maracanã, entre tantos outros. De acordo com Fratucci (2005, p.82), "o Rio de Janeiro sempre foi, e continua sendo, o estado brasileiro onde a atividade turística apresenta dimensões mais marcantes, tanto para a sua economia, quanto para sua estrutura sociocultural". Porém, a atividade também apresenta dinamicidade no interior, o que é destacado por este autor, quando diz que o estado

tem no turismo um dos suportes de desenvolvimento mais importante, apresentando sobreposto ao seu território uma rede bastante ampla de nós/lugares turísticos, interligadas por uma extensa malha de rodovias, hidrovias, ligações aéreas (a malha ferroviária existente praticamente não é utilizada pelo sistema turístico) e de uma complexa rede de comunicações. 
O discurso oficial corrobora com o autor, visto o Caderno de Turismo do estado que destaca a atividade turística como influenciada pela vasta diversidade de paisagens, características topográficas e climáticas, além das singularidades culturais encontradas no estado do Rio de Janeiro, para em seguida alertar sobre a importância que representa para alguns municípios e o estado de maneira geral, destacando que tais práticas muitas vezes surgem de possibilidades até então pouco exploradas em características peculiares a cada município (GOMES, 2010).

É na década de 1960 que tem início o ordenamento territorial a partir do turismo no estado do Rio de Janeiro, visto que neste período começa a haver uma preocupação institucional em relação à atividade, com a criação do Instituto Brasileiro de Turismo (atual Embratur) em nível nacional e da Companhia de Turismo do Estado do Rio de Janeiro (Flumitur), segundo Fratucci (2005). Já nos anos 1970, começa a ser mais evidente o processo de interiorização da atividade, muito em função da fusão dos estados da Guanabara e do Rio de Janeiro em 1975, o que ocasionou a transferência da sede da Flumitur de Niterói para o Rio de Janeiro, passando a desenvolver ações que tinham como foco principal o interior, visto que o turismo da capital era gerido pela Riotur (FRATUCCI, 2005).

Buscando evidenciar tal preocupação dos agentes públicos no desenvolvimento turístico do interior, selecionamos Cabo Frio, centro turístico nacional, de acordo com a Embratur, na década de 1980. Nesta mesma década foi desenvolvido o Plano indutor de investimentos turísticos na Região dos Lagos, do governo do estado do Rio de Janeiro com apoio do governo da Catalunha. Fratucci $(2005$, p.91), tece considerações a respeito das razões para elaboração e objetivos do plano.

\begin{abstract}
A justificativa para a elaboração desse plano estava calcada em um diagnóstico do turismo brasileiro da época, que apontava para o fato de, apesar da forte demanda potencial (nacional e internacional) existente, o Rio de Janeiro não oferecer um produto turístico coerente e compatível com as exigências do mercado. Segundo relatórios da época, esse desajuste era causado pela ausência de uma política de turismo específica para um segmento de mercado, o que demonstrava a ausência de um produto turístico altamente qualificado e competitivo internacionalmente. A escolha da Região dos Lagos do Rio de Janeiro baseou-se na sua proximidade com a cidade do Rio de Janeiro e com o Aeroporto Internacional (média de 60km); nas características fisiográficas locais: grande extensão do litoral, clima tropical, baixo índice pluviométrico e inverno com temperaturas médias em torno de 20ㅇ C; na sua topografia ideal para implantação de campos de golfe e, nas características culturais dos seus centros urbanos.
\end{abstract}

À época foram elaboradas diversas propostas para aplicação do plano, porém uma série de dificuldades políticas o inviabilizaram, como alterações nas legislações municipais quanto ao uso do solo, a ausência de recursos financeiros suficientes e a eleição estadual, que colocou no poder um novo governo (FRATUCCI, 2005).

Silva $(2008$, p.272) ressalta os resultados obtidos recentemente pelos municípios do Rio de Janeiro que tem o turismo como principal atividade, pois "há algum tempo podem ser relacionados entre os que 
apresentam as maiores taxas de crescimento, o que, de maneira geral, só confirma uma tendência mundial nesse sentido". Porém, há no estado do Rio de Janeiro uma variedade considerável de tipologias relacionadas ao turismo, o que contribui decisivamente para o crescente número de visitantes, visto que há opções para os mais variados públicos.

Cumpre fazer referência que além das políticas na escala nacional e estadual, não podemos deixar de mencionar as respectivas Secretarias Municipais de Turismo ou órgãos similares. Estas secretarias desenvolvem políticas específicas com relação aos atrativos e atividades que conferem singularidades aos municípios turísticos. Incentivam através do marketing, calendários e folders, promovendo a atividade em tela. Podemos exemplificar na Região das Baixadas Litorâneas o município de Armação dos Búzios, que procura difundir uma imagem relacionada aos aspectos da natureza, especialmente os ambientes de praia. Outro exemplo é a Costa Verde, que difunde uma imagem de paraíso em seus prospectos como uma forma de "vender" esse trecho do litoral sul fluminense com suas belezas naturais.

Objetivando traçar um panorama da atividade nos dias atuais em território fluminense, recorremos à classificação elaborada pelo Ministério do Turismo $(2019)^{1}$, o qual categorizou os municípios brasileiros de acordo com o desempenho econômico de cada um destes no setor, classificando-os de " $A$ " a " $E$ ". Através do quadro 1 e da figura 1, procuramos destacar aqueles que apresentaram resultados mais expressivos no estado do Rio de Janeiro, evidenciando a consolidação do turismo como importante atividade econômica.

Quadro 1. Municípios do estado do Rio de Janeiro inseridos na categoria $A^{2}$. Fonte: Ministério do Turismo, 2019. Elaborado por Nunes (2019).

\begin{tabular}{|l|l|}
\hline Município & Região Turística \\
\hline Angra dos Reis & Costa Verde \\
\hline Armação dos Búzios & Costa do Sol \\
\hline Cabo Frio & Costa do Sol \\
\hline Macaé & Costa do Sol \\
\hline Paraty & Costa Verde \\
\hline Petrópolis & Serra Verde Imperial \\
\hline Rio de Janeiro & Metropolitana \\
\hline
\end{tabular}

A partir do quadro 1 e da figura 2, Costa (2010, p.82) afirma algo já diagnosticado, que a sociedade atual tem nos ambientes naturais os principais polos de atração turística. Prossegue analisando especificamente a praia, visto que, segundo ele, esta

\footnotetext{
${ }^{1}$ Cumpre fazer referência que outras tipologias foram elaboradas, além desta apresentada pelo Ministério do Turismo em 2019. Para consulta sobre as mesmas, ver Ribeiro (2003) e NEGEF (2010).

2 Instrumento elaborado pelo Ministério do Turismo para identificar o desempenho econômico no setor para os municípios que constituem o Mapa do Turismo Brasileiro. A categoria " $\mathrm{A}$ " representa os municípios com maior fluxo turístico e maior número de empregos e estabelecimentos formais no setor de hospedagem.
} 
é potencialmente turística por dois motivos básicos: a segurança que esse ambiente confere, com suas reentrâncias e o seu imenso e belo horizonte, que suscita nos seres humanos o sentimento de aventura. Importante ressaltar que a praia também permite uma fusão entre atividades econômicas e recreativas, portanto constitui também um ambiente de fixação populacional.

Figura 2 - Distribuição espacial dos municípios fluminenses inseridos na categoria. A Fonte: Ministério do Turismo, 2019

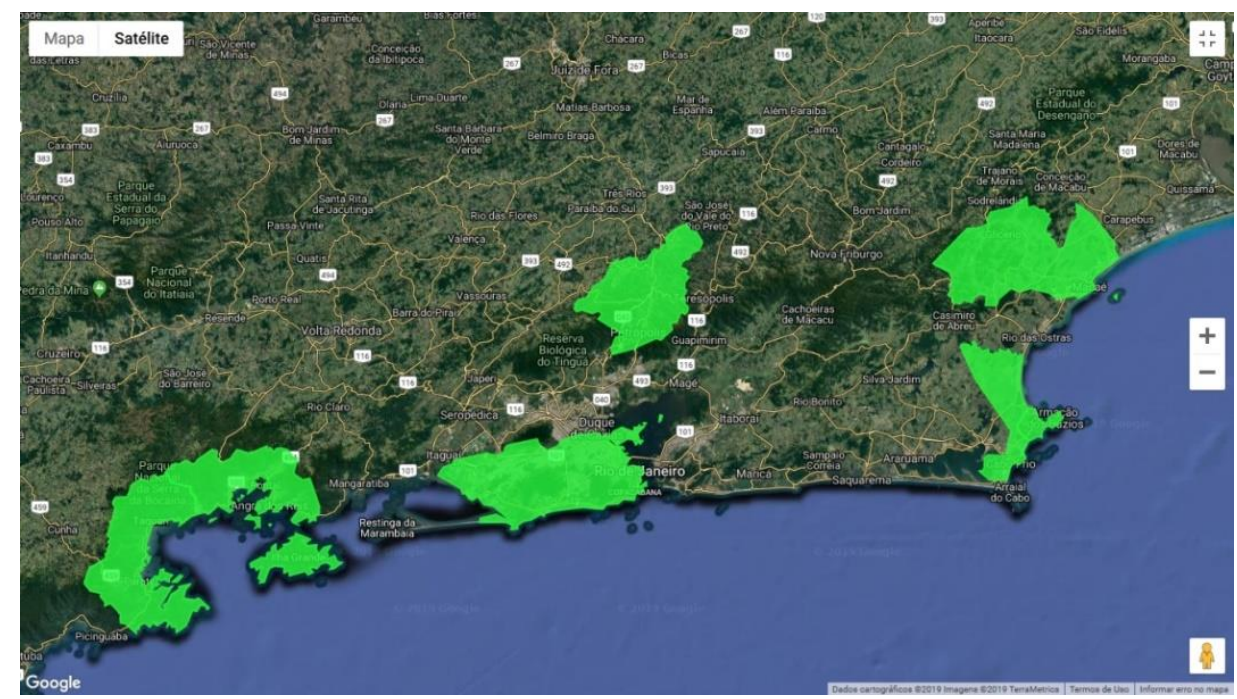

Após a apresentação das funções turísticas e da categorização dos municípios do estado, no próximo segmento discutiremos o turismo a partir de municípios específicos, evidenciando aspectos relacionados à inserção da atividade e do cenário verificado atualmente.

\section{O papel do turismo nos municípios fluminenses de categoria $\mathrm{A}$}

Buscando finalizar este artigo sobre a dimensão espacial da atividade turística no estado do Rio de Janeiro, abordaremos a temática a partir dos municípios inseridos na categoria A da classificação do Ministério do Turismo para 2019, visto que estes são aqueles de maior destaque na escala nacional, conforme variáveis indicadas na nota de rodapé 2 deste artigo. Para tanto, estabelecemos a ordem de análise dos municípios a partir das regiões turísticas em que estão inseridos, iniciando com aqueles pertencentes à Costa Verde, passando pelos que se localizam na Costa do Sol, finalizando com a Serra Verde Imperial e a Região Metropolitana, respectivamente.

No caso de Angra dos Reis, destacamos o processo de ocupação do território que atualmente delimita o município, extremamente vinculado ao processo de colonização do país, com a chegada dos portugueses 
em seu litoral em um primeiro momento e posterior ocupação do interior. Em função das condições propiciadas pelo sítio, a denominada Baía da llha Grande exerce importante função portuária, para escoamento de ouro vindo de Minas Gerais. Posteriormente, o município teve na produção cafeeira sua principal atividade econômica.

No final dos anos 1970, Angra dos Reis é escolhida como sede de importantes projetos, como ressalta Corrêa (2010), exemplificados pelo estaleiro Verolme e as Usinas Nucleares Angra I e II, contrastanto com a atividade turística, empreendimento que proporciona a chegada de fluxos cada vez maiores ao município da Costa Verde fluminense, com a construção da Rodovia Rio-Santos na referida década.

Tratando dos elementos angrenses atrativos aos turistas (figura 3), Corrêa (2010, p.118) aponta que Angra dos Reis é internacionalmente conhecida por seus recursos naturais, como as 365 ilhas e as duas mil praias exaustivamente mencionadas em sites e panfletos encontrados em estabelecimentos turísticos do município e de outras localidades. A condição atribuída de paraíso natural, assim como a ideia construída acerca de sua vocação turística se apresentam como alguns dos argumentos que impulsionam o setor de turismo na localidade.

Angra dos Reis é internacionalmente conhecida por seus recursos naturais, como as 365 ilhas e as duas mil praias exaustivamente mencionadas em sites e panfletos encontrados em estabelecimentos turísticos do município e de outras localidades. A condição atribuída de paraíso natural, assim como a ideia construída acerca de sua vocação turística se apresentam como alguns dos argumentos que impulsionam o setor de turismo na localidade.

Figura 3. Ambiente de praia no município de Angra dos Reis. Fonte: Nathan Nunes, 2013.

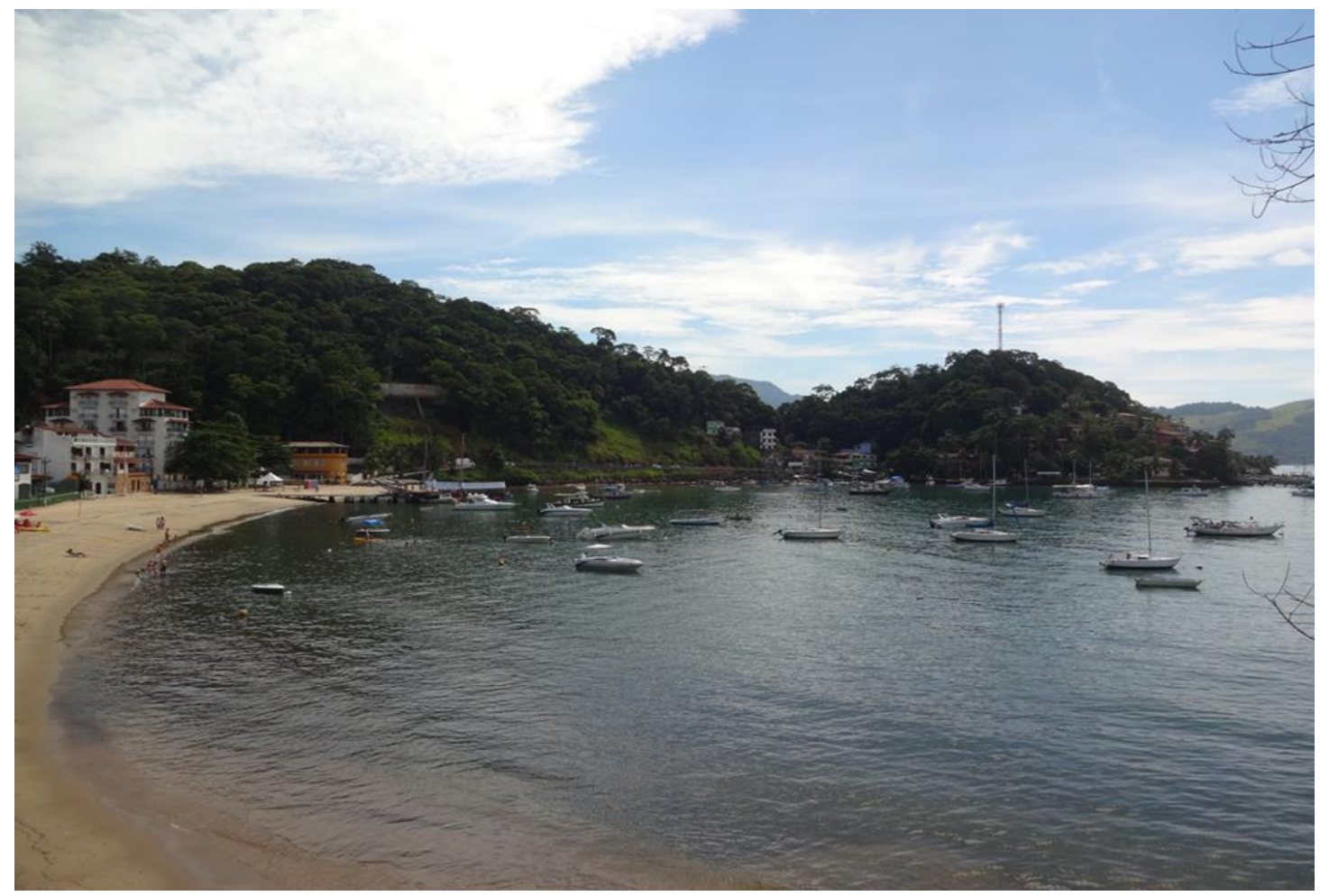


Para além do distrito sede, destaca-se também o distrito de Ilha Grande. Nas palavras de Costa (2012, p.104),

\begin{abstract}
o turismo se aproveita da beleza cênica da Ilha Grande para permanecer, ainda hoje, como principal atividade econômica deste distrito fluminense. A Ilha Grande segue a orientação turística do seu município de origem, Angra dos Reis, que é pautada na concretização do ambiente náutico.
\end{abstract}

Entretanto, é necessário ressaltar o caráter segregador do turismo neste caso, visto que é possível observar o desenvolvimento da atividade em áreas específicas da ilha, com a desvalorização de áreas outrora importantes economicamente, como aquelas ocupadas por população caiçara (COSTA, 2012).

Na mesma região turística, a Costa Verde, está situado o município de Paraty. O caso deste município reflete o cenário verificado em diversos outros no Brasil, onde o turismo apresenta-se como responsável por transformações espaciais que afetam significativamente a sociedade.

Paraty, assim como Angra dos Reis, no século XVII serviu como entreposto para escoamento aurífero, posteriormente exerceu a mesma função para a produção cafeeira. Após tais atividades econômicas, o município retorna no fim do século XX ao grande circuito da economia brasileira através do turismo, conforme destaca Silva (2008). Ainda segundo este autor, a atividade ocasionou inúmeras transformações no município, notadamente no que tange a especialização de serviços, restaurantes e pensões.

A primeira leva de turistas em Paraty era composta pelos chamados hippies, que praticavam o chamado turismo "mochileiro", caracterizado por acampamentos ou hospedagem de baixo custo. Porém, Silva (2008) afirma que a dimensão do turismo neste município da Costa Verde é alterada na década de 1970, com a chegada da classe média a Paraty, facilitada pela abertura da Rodovia Rio-Santos.

Atualmente, a Secretaria de Turismo de Paraty (conforme figura 3) aponta um calendário anual bastante diversificado para atender diferentes segmentos de visitantes, destacando-se como ponto alto a FLIP (Festa Literária Internacional de Paraty), que ocorre no Mês de julho, e o Festival da Cachaça, Cultura e Sabores de Paraty.

Para concluir a abordagem acerca de Paraty, é fundamental regressar a década de 1950, quando seu conjunto histórico foi tombado pelo Instituto do Patrimônio Histórico e Artístico Nacional. A beleza arquitetônica (figura 4) característica do Brasil colonial atrai até os dias atuais importantes fluxos turísticos, além de seus parques, reservas ecológicas e praias. 
Figura 4. Calendário anual de eventos de Paraty. Fonte: Secretaria de Turismo de Paraty, 2019.

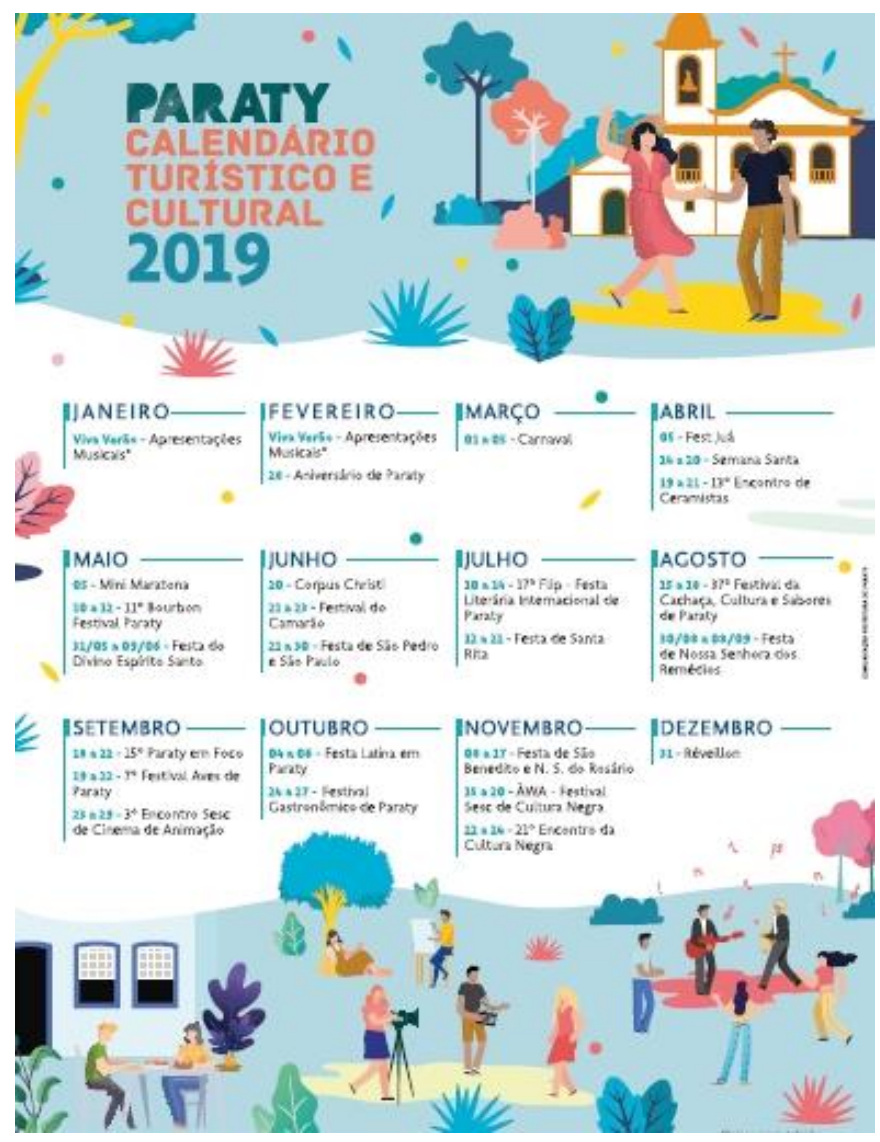

Figura 5. Igreja Nossa Senhora dos Remédios, em Paraty. Fonte: Nathan Nunes, 2019.

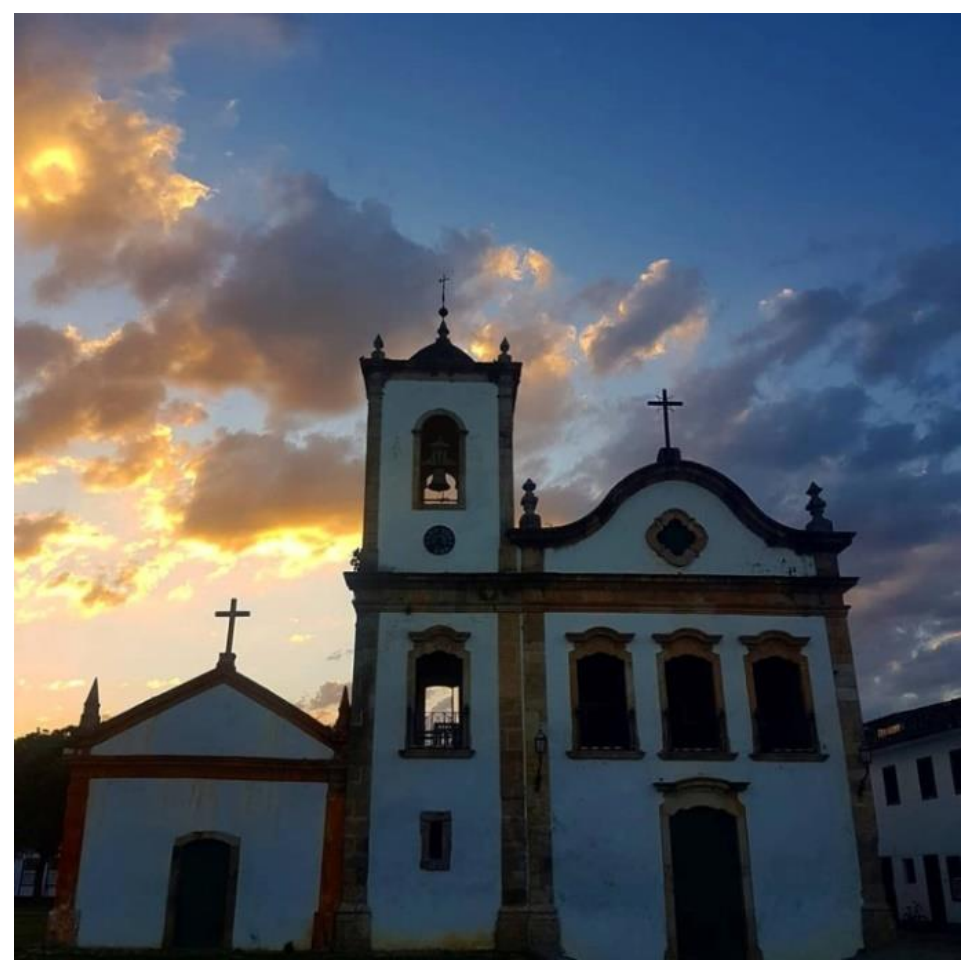


Após caracterizar os dois municípios da Região Turística Costa Verde, passemos àqueles que se destacam na classificação do Ministério do Turismo (2019) localizados nas Regiões de Governo das Baixadas Litorâneas e Norte Fluminense, e na Região Turística Costa do Sol. São eles: Armação dos Búzios, Cabo Frio e Macaé.

Quanto a Armação dos Búzios, possui história mais recente enquanto município emancipado, mas o processo de ocupação de seu território é extremamente antigo, visto antes da chegada dos portugueses já habitavam seu território tribos indígenas. Após a inserção portuguesa, o atual município de Armação dos Búzios verifica uma exploração econômica vinculada a atividade do pau- brasil.

Posteriormente, o século XVIII é marcado pela pesca de baleias na enseada de Armação dos Búzios, prática que perduraria até 1767 , quando a presença do animal já era rara.

No que diz respeito ao turismo, o município é conhecido internacionalmente, tendo a década de 1960 como marco inicial do início do desenvolvimento mais destacado da atividade turística, em função da presença da atriz francesa Brigitte Bardot na então vila de pescadores ainda pertencente ao município de Cabo Frio (NUNES, 2017).

Atualmente, a atividade é a de maior destaque na economia deste município localizado nas Baixadas Litorâneas, sendo valorizadas pelos turistas especialmente suas praias (figura 5), diretamente responsáveis pela classificação do mesmo na categoria A do Ministério do Turismo, confirmando a relevância da atividade para sua economia, bem como a expressividade municipal não apenas nos contextos regional e estadual, mas também em âmbito nacional.

Através de trabalho de campo realizado no ano de 2016, foi possível verificar uma busca pela manutenção do perfil turístico municipal, através da atuação dos agentes promotores, sejam eles oriundos do setor público ou da esfera privada. Há uma tentativa de romantizar os atrativos/paisagens do município, através da associação entre linguagem e imagem na criação de representações que cativem o observador. Frases como "a natureza convida você e sua família para um encontro inesquecível" e "desfrute dos pequenos paraísos iluminados pelo sol e bordados pelo mar" são acompanhados de imagens fotográficas diversas, mas onde predominam as relacionadas aos ambientes de praia (figura 6). 
Figura 6. Praia João Fernandes, em Armação dos Búzios Fonte: Nathan Nunes, 2016.

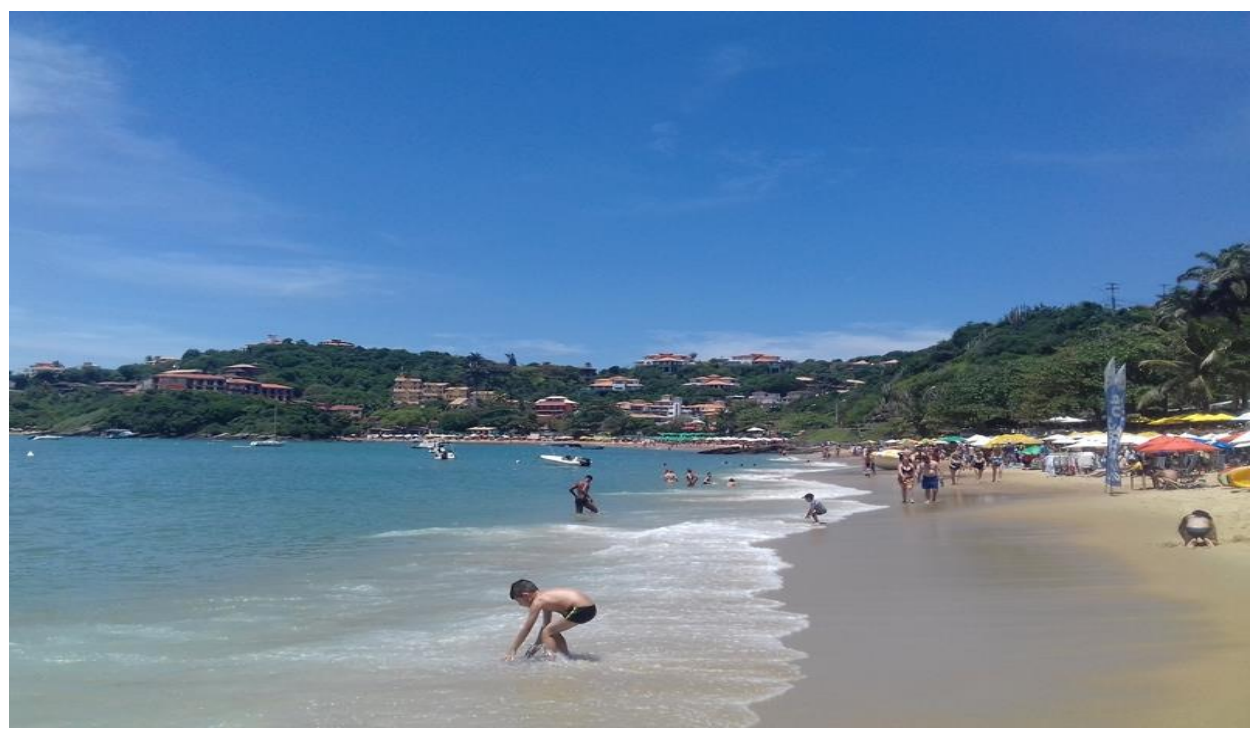

A península buziana registra mais de 30 praias, podendo-se destacar Geribá, Tucuns, Rasa, Brava, Tartaruga, João Fernandes, Azeda, entre outras.

Cumpre fazer referências ao festival gastronômico de Armação dos Búzios, que atrai quantidade expressiva de visitantes/turistas para a sede municipal no mês de julho, no qual é enfatizada a culinária caiçara e os frutos do mar.

Figura 7. Material publicitário referente a Armação dos Búzios Fonte: Secretaria de Turismo de Armação dos Búzios, s/d.

The nature invites you and your family to an unforgettable encounter.
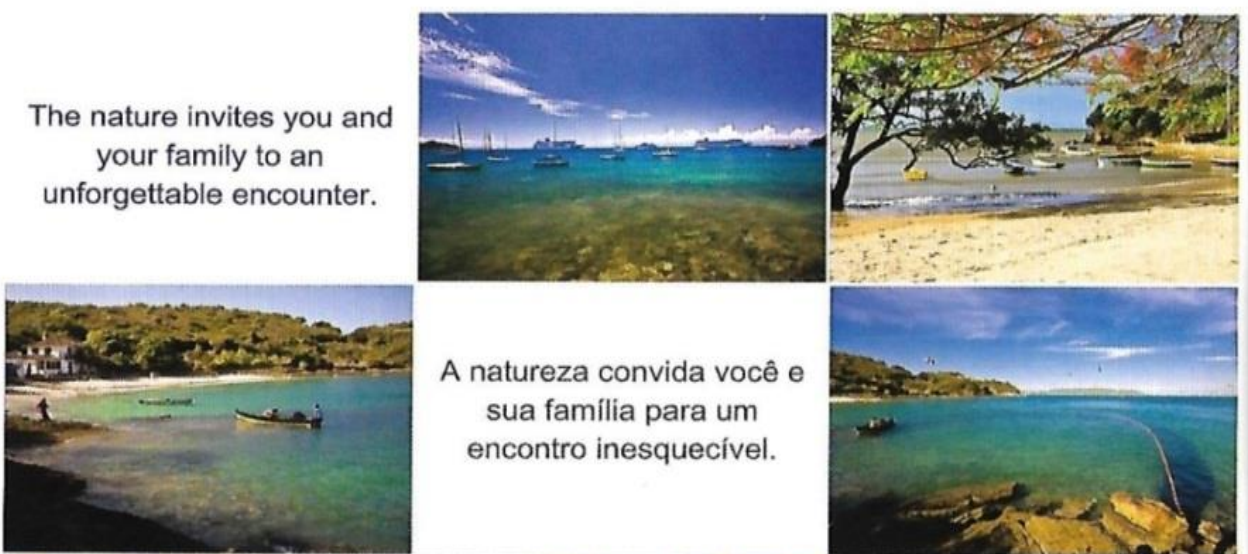

A natureza convida você e sua familia para um encontro inesquecível.
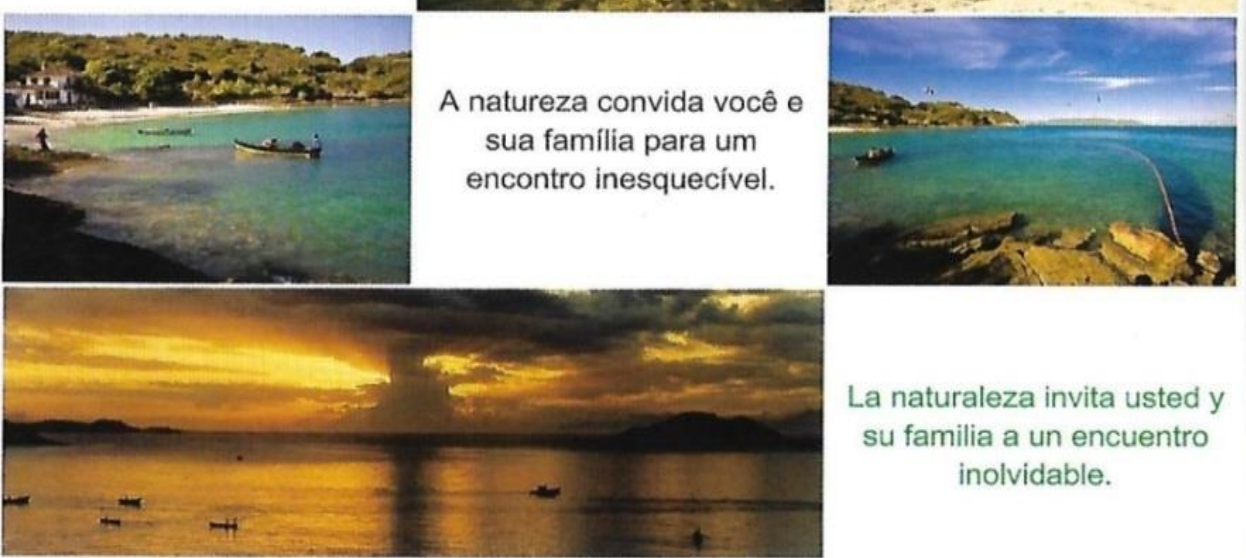

La naturaleza invita usted y su familia a un encuentro inolvidable. 
Em relação a Cabo Frio, cabe destacar que deste município se emanciparam diversos outros que compõem a região de governo das Baixadas Litorâneas, na qual o mesmo exerce um papel de centralidade que perdura até os dias atuais. Sobre a região, esta observou a partir de década de 1970 um incremento econômico e populacional em função especialmente da melhoria das condições de acesso a partir da Região Metropolitana. Na década de 1990 emerge ainda o setor petrolífero, com destacada influência na região, visto que quatro de seus municípios (Armação dos Búzios, Cabo Frio, Casimiro de Abreu e Rio das Ostras) estão na denominada Zona de Produção Principal (NUNES, 2015).

Barcellos (2016) afirma que o desenvolvimento econômico de Cabo Frio ocorreu historicamente a partir de recursos oriundos da pesca e da produção salineira, havendo uma modificação deste cenário a partir da fusão entre os estados da Guanabara e do Rio de Janeiro, em 1975, pois foram criados planos de integração para o território fluminense, incluindo eixos rodoviários que articulassem o recém criado estado do Rio de Janeiro. Com estas novas condições de acesso e incentivos econômicos diversos, "o turismo torna-se atividade marcante" (BARCELLOS, 2016, p.28).

De acordo com a Secretaria de Turismo, no ano de 2016 o número de turistas que chegaram a Cabo Frio na chamada alta temporada ultrapassou 800 mil pessoas, o que representa cerca de quatro vezes o tamanho da população local. O município é ainda importante exemplo para a análise do fenômeno da segunda residência em território fluminense, pois de acordo com o IBGE (2010), 33,0\% dos domicílios deste município eram de uso ocasional.

Cabe ressaltar ainda que, após a divulgação da classificação elaborada pelo Ministério do Turismo, a prefeitura de Cabo Frio passou a utilizar a inserção do município na categoria A como instrumento de marketing, conforme pode ser observado na figura 8, proporcionando a "venda" e propaganda do mesmo, na tentativa de atrair mais visitantes.

Figura 8. Divulgação da classificação turística municipal pelo poder público de Cabo Frio Fonte: Prefeitura de Cabo Frio, 2019.

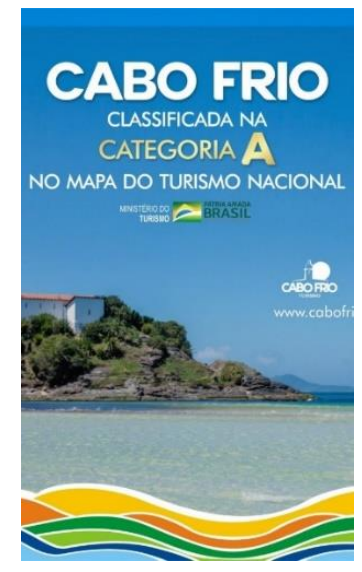


No caso de Macaé, a relação entre os municípios classificados na categoria A apresenta muitas especificidades. $O$ destaque em termos econômicos recentemente tem ocorrido em função da posição geográfica deste município da Região de Governo Norte Fluminense, fazendo com que este fosse escolhido como sede da base operacional da Petrobrás e, consequentemente, de importantes empresas ligadas à atividade petrolífera. Neste contexto, Macaé passa a exercer centralidade regional, bem como Campos dos Goytacazes, o que influencia diretamente na chegada de fluxos populacionais e na expansão urbana.

Tratando de maneira direta do setor turístico, o Ministério do Turismo (2018, online) destaca a expressividade macaense em relação ao turismo de negócios, afirmando que o referido município "recebe empresários e trabalhadores da indústria offshore todos os dias", e complementa, ao constatar que "hoje possui um dos maiores parques hoteleiros do estado, com cerca de 10 mil leitos. Como resultado deste investimento, o turismo de negócios já responde por 10\% do PIB do município". Porém, o território macaense apresenta uma diversidade de paisagens, distintas áreas de topografia diferenciadas, dentre elas as praias, localizadas em cordões arenosos, como a dos Cavaleiros, diante de localidades em áreas de serra, exemplificado pelo distrito de Sana.

Porém, o ministério ressalta a tendência recente conferido pela Secretaria Municipal de Turismo a modalidades que valorizem Macaé enquanto destino voltado também para o lazer. Em reportagem veiculada no endereço eletrônico do Ministério do Turismo, é apresentada uma entrevista com o secretário municipal para a pasta, na qual ele ressalta a potencialidade macaense, visto que o município possui praias (figura 9), serra e cachoeiras, além de festivais gastronômicos e culturais, destacados no calendário turístico anual, este elaborado a fim de reduzir a sazonalidade da atividade.

Figura 9. Praia dos Cavaleiros, em Macaé Fonte: Rui Porto Filho, 2018.

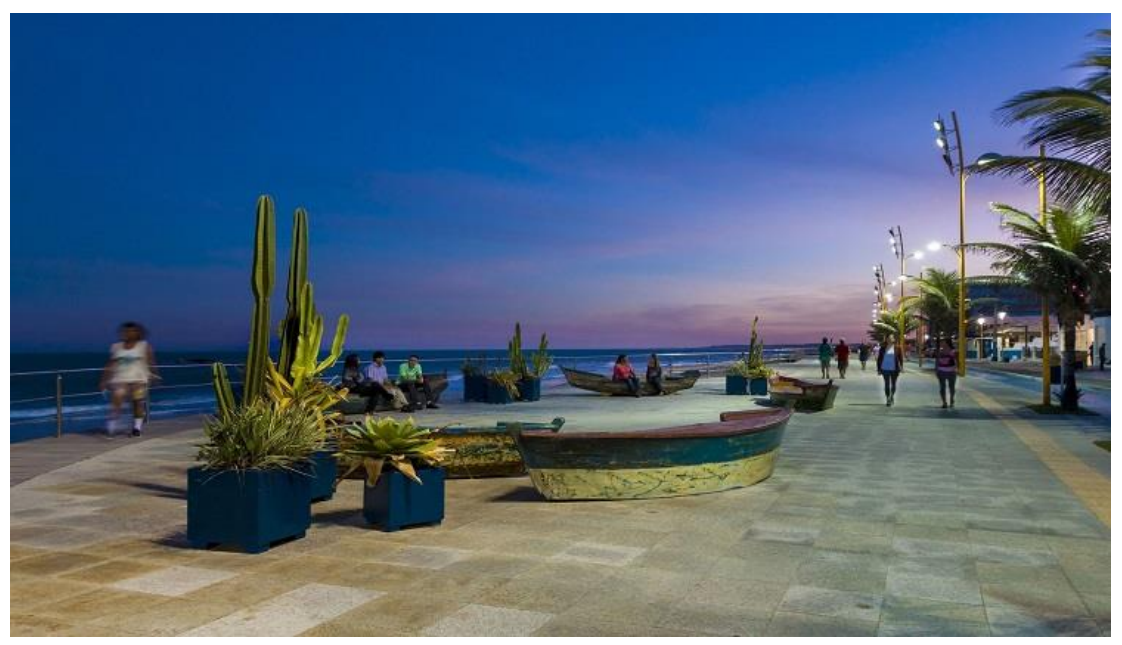


Após discorrer sobre os municípios selecionados na categoria A pelo Ministério do Turismo na Região Turística da Costa do Sol, passemos tecer considerações sobre Petrópolis, localizado na Região de Governo Metropolitana e na região turística Serra Verde Imperial. O referido município é também conhecido como cidade imperial, fato que será explorado de maneira insistente pelos agentes promotores do turismo. Tal nomenclatura remete ao histórico municipal, haja vista que no período do Brasil Império, especialmente $D$. Pedro II utilizava o atual município como local de fuga dos verões extremamente quentes do Rio de Janeiro. A presença do imperador e sua família proporcionou, portanto, a inserção de marcas presentes até hoje na paisagem petropolitana, como o Palácio Imperial e a Catedral de São Pedro de Alcântara, fixos que mantém uma expressiva centralidade.

Além dos fixos diretamente relacionados com períodos onde o Brasil era governado por portugueses, Petrópolis apresenta ainda elementos mais recentes, que passam também a ser incorporados ao produto turístico. Neste sentido, é possível destacar o Palácio Quitandinha, construído na década de 1940, a casa de Santos Dumond, além das diversas cervejarias artesanais, costumeiramente relacionadas a tradições europeias. Seus distritos são de extrema importância para a referida atividade, destacando-se Itaipava, Correias, entre outros, ofertando diferentes atrações voltadas para o contato com a natureza, a gastronomia e a cultura.

Adentremos pela principal "porta" de Turismo em território fluminense, a capital do Rio de Janeiro, a cognominada "Cidade Maravilhosa" (COSTA, 2014). Nas últimas décadas verificamos que há uma preocupação crescente na valorização e criação de elementos a serem vendidos externamente, pautando a atuação do poder público especialmente na reestruturação urbana que se apoia nos megaeventos esportivos sediados pela cidade. Barre $(2013$, p.46) entende que

os megaeventos seriam então o pretexto para repensar, planejar e executar uma transformação profunda da cidade do Rio, afim de urgentemente fazer dela uma cidade "de fluxos", "global", "cosmopólita", "inteligente", "criativa”, "tecnológica", "festiva”, "sede" (host city), e talvez, sobretudo, afinal, "(ainda mais) atrativa".

Entre os anos de 2007 e 2016 o Rio de Janeiro sediou três dos principais eventos esportivos mundiais, os Jogos Pan-Americanos, a Copa do Mundo de Futebol e as Olimpíadas de verão, que ocasionaram a criação de variados fixos ligados ao esporte no espaço urbano carioca, como o Estádio Olímpico João Havelange posteriormente renomeado para Estádio Olímpico Nilton Santos - (figura 10), o Parque Aquático Maria Lenk, a Arena Multiuso, o Complexo esportivo de Deodoro, diversas instalações que compõem o Parque Olímpico, dentre outros, além de intervenções sobre equipamentos que fazem parte da paisagem carioca há décadas, como as reformas pelas quais passou o estádio do Maracanã. Os referidos fixos são inseridos então no produto turístico carioca, somando-se a outros elementos, como o Pão de Açúcar e o Cristo Redentor, tornando-se 
frequentes nas representações paisagísticas criadas com a finalidade de divulgar a capital fluminense no Brasil e no exterior.

Cumpre fazer referência que muitos destes equipamentos estão abandonados e sem utilização no momento atual, principalmente aqueles localizados na zona oeste carioca, mais precisamente na Barra da Tijuca, bairro que teve instalações importantes para os Jogos Pan-Americanos de 2007 e os Jogos Olímpicos de 2016.

Figura 10. Cartão postal com o estádio do Engenhão como elemento central Fonte: Paulo Romeu, 2007

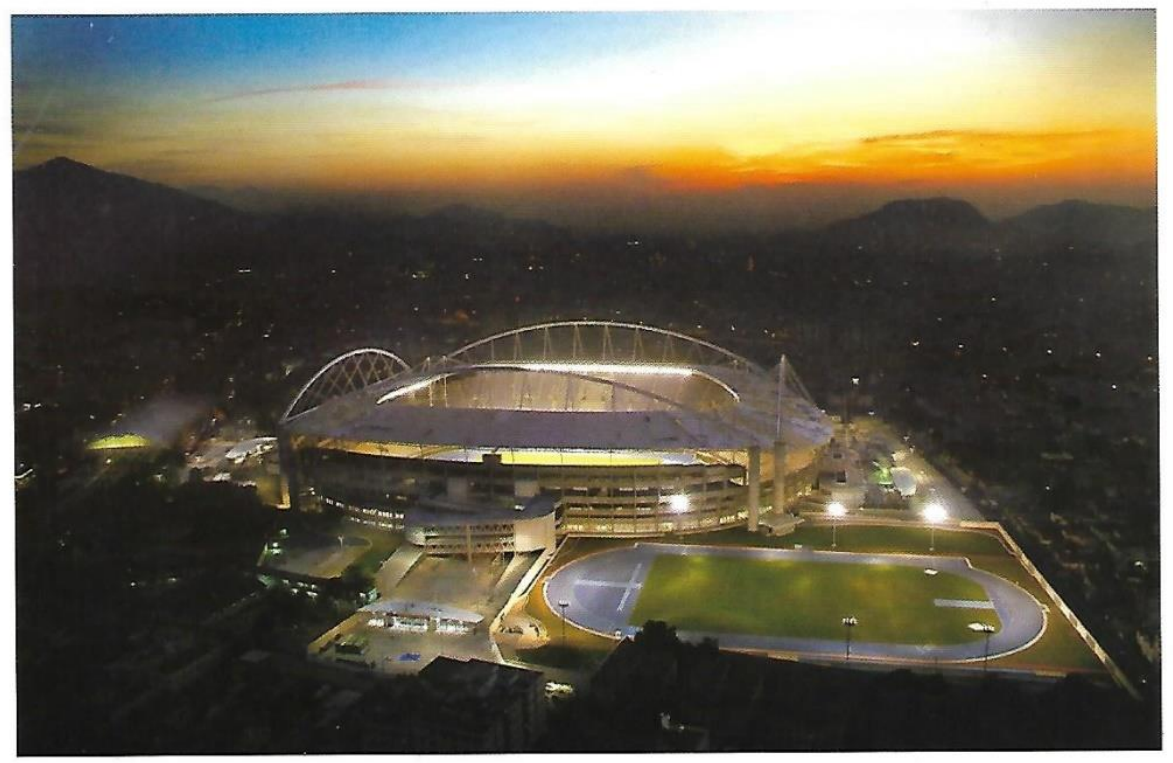

Associados a outros elementos, como a predisposição do quadro natural, os elementos históricos e os transportes, a cidade do Rio de Janeiro constitui-se como um dos principais destinos brasileiros segundo classificação do Ministério do Turismo (2019), que a inclui na categoria A, juntamente com outros 61 municípios brasileiros. Ribeiro (2003), ao desenvolver uma tipologia das localidades com atividades turísticas e de apoio insere a capital fluminense no tipo (função) litorânea e subtipo diversificada, caracterizada por englobar diversas modalidades de turismo. Estas duas categorizações evidenciam, portanto, a variedade da oferta e importância adquirida pela atividade turística para a economia carioca.

Fratucci (2005) apresenta tentativas de desenvolvimento do turismo, sendo válido ressaltar algumas daquelas que inserem a cidade do Rio de Janeiro em seu recorte, como o Projeto Turis (1973-1975); a identificação do espaço turístico estadual (1979-1981), proposta realizada pelo Instituto Brasileiro de Turismo (EMBRATUR) e desenvolvida no estado do Rio de Janeiro pela Companhia de Turismo do Estado do Rio de 
Janeiro (FLUMITUR); a Campanha Cidades Maravilhosas do Estado do Rio de Janeiro (1988-1990), estabelecida pela TurisRio; o Plano Diretor de desenvolvimento de polos de turismo náutico (1988-1990); o Plano Diretor de Turismo do estado do Rio de Janeiro (1997-2001). Mais recentemente, verificamos a proposição de campanhas como "Rio de Janeiro a Janeiro", realizada através da parceria entre a prefeitura municipal, o Governo Federal e empresários, tendo como foco o aumento do fluxo de turistas através da exposição do potencial turístico da cidade.

As iniciativas apresentadas constituem algumas das propostas estabelecidas pelo poder público para a gestão do turismo, pautando-se muitas vezes em recortes espaciais amplos, mas que incluem a cidade Rio de Janeiro.

A partir do que foi exposto procuramos evidenciar algumas práticas e localidades privilegiadas pelos fluxos turísticos em território fluminense, cabendo ressaltar, entretanto, que há diversos outros municípios e tipologias de imensa representatividade para a atividade no contexto estadual, mesmo que não classificadas como de nível A pelo Ministério do Turismo, podendo-se mencionar municípios localizados no Vale do Paraíba Fluminense, como Itatiaia, Vassouras e Paraíba do Sul; na Região Serrana, como Teresópolis e Nova Friburgo; na Região das Baixadas Litorâneas, como Saquarema, Araruama e São Pedro da Aldeia; entre outros.

\section{PARA NÃO CONCLUIR}

O território fluminense tem nas atividades de lazer importante fator no que diz respeito a seu desenvolvimento social e econômico, notadamente quando tratamos das atividades relacionadas ao turismo, sendo o referido recorte espacial uma das unidades federadas de maior importância para a promoção do Brasil enquanto destino de visitantes nacionais e estrangeiros.

Pudemos constatar a relevância de elementos como a história dos municípios e as atividades econômicas neles desenvolvidas; a melhor acessibilidade ao interior, especialmente através da construção e melhorias de rodovias que ligam a metrópole ao interior, a partir da década de 1970; e o elemento físico/natural, imensamente valorizado por agentes promotores e consumidores do turismo quando tratamos do recorte espacial em tela.

Apesar da representatividade da capital estadual, exacerbada após a realização de megaeventos esportivos neste século 21, a consagrada “Cidade Maravilhosa, também identificamos diversos municípios do interior que conseguiram aproveitar suas possibilidades turísticas, como são os casos de Armação dos Búzios, Cabo Frio, Paraty e Angra dos Reis. Estes, de acordo com o Ministério do Turismo, são aqueles nos quais o 
turismo apresenta maior grau de desenvolvimento no estado, estando entre os 62 no país que encontram-se dotados de elementos necessários para compor a categoria A da referida classificação.

Mas, mesmo tratando de uma atividade que traz divisas em níveis estadual e municipal, os órgãos competentes em diferentes instâncias poderiam elaborar políticas mais eficientes, que permitissem a inclusão de maior parte da população local, oferecesse incentivo educacional e qualificação da mão de obra, e promovesse infraestrutura e empreendimentos mais adequados e com melhor localização, não copiando modelos de países e cidades centrais (caso de modelos europeus), que muitas vezes não se adequam às realidades locais, excluindo a população. Tais questões ficam para discussão em uma outra oportunidade.

\section{REFERÊNCIAS}

BARBOSA, Talita Prado; SILVA, Odair Vieira da. Origens e significados do lazer. In: Revista Científica Eletrônica de Turismo. Ano III. N.14. Rio de Janeiro, 2011.

BARCELLOS, Cláudia Márcia. Mobilidade urbana: efeitos causados pelo turismo de massa no município de Cabo Frio. 2016. 100f. Monografia (Graduação em Turismo) - Universidade Federal Fluminense. Niterói: Faculdade de Turismo e Hotelaria, 2016.

BARRE, Jorge de La. Choque de futuro: o Rio dos Megaeventos. In: Revista O Social em Questão. Rio de Janeiro, ano XVI, no29, 2013. P.43-68.

CIDE.1997, 2014. Estado do Rio de Janeiro: território. Rio de Janeiro: CIDE, 80p.

CORRÊA, Renata Da Silva. Diferentes territórios, territorialidades divergentes: os territórios do turismo em Angra dos Reis (RJ). In: MARAFON, Glaucio José; RIBEIRO, Miguel Angelo (orgs.). Revisitando o Território Fluminense III. Rio de Janeiro: Gramma, 2010. P.113-134.

COSTA, Amanda Danelli. História e Cultura Urbana Carioca: a natureza turística do Rio de Janeiro entre a Cidade das Letras e a Cidade Maravilhosa. In: Turismo e Território no Brasil e na Itália: novas perspectivas, novos desafios. EdEUERJ, 2014. pp. 123-161.

COSTA, Romulo de Oliveira. A (re)produção do lugar turístico aliado à lógica dos ambientes de atração permanente: o exemplo da expansão do fenômeno do Ecoturismo na Ilha Grande - Angra dos Reis (RJ). In: MARAFON, Glaucio José; RIBEIRO, Miguel Angelo (orgs.). Revisitando o Território Fluminense III. Rio de Janeiro: Gramma, 2010. P.77-88.

COSTA, Romulo de Oliveira. A Paisagem como recurso capitalista para o Turismo: o exemplo de apropriação da paisagem da llha Grande - Angra dos Reis/RJ. In: MARAFON, Glaucio José; RIBEIRO, Miguel Angelo (orgs.). Revisitando o Território Fluminense IV. Rio de Janeiro: Gramma, 2012. P.91-110.

FRATUCCI, A. C.. A formação e o ordenamento territorial do turismo no estado do Rio de Janeiro. In: Bartholo, Roberto; Delamare, Mauricio; Badin, Luciana. (Org.). Turismo e Sustentabilidade no Estado do Rio de Janeiro. 1ed. Rio de Janeiro: Garamond, 2005, v. 1, p. 81-109.

GOMES, João Carlos (org.). Caderno de turismo do Estado do Rio de Janeiro : passaporte para o desenvolvimento do Estado. Rio de Janeiro: Fecomércio, 2010.

IBGE. Censo Demográfico, 2010.

MARAFON, Glaucio José (et al.). Geografia do Estado do Rio de Janeiro. Rio de Janeiro: Gramma, 2011.

MENOIA, Thelma Regina Marialva. Lazer: história, conceitos e definições. 2000. 22f. Monografia (Graduação em Recreação e Lazer UNICAMP). Campinas, 2000.

MINISTÉRIO DO TURISMO. Categorização dos municípios das Regiões Turísticas do Mapa do Turismo Brasileiro. Brasília, 2019. 
MINISTÉRIO DO TURISMO. Uma grata surpresa chamada Macaé. 2018. Disponível em: http://www.turismo.gov.br/\%C3\%BAltimasnot\%C3\%ADcias/10773-uma-grata-surpresa-chamada-maca\%C3\%A9.html . Acesso em 16 de outubro de 2019.

MOTA, Carlos Guilherme; LOPEZ, Adriana. História do Brasil: uma interpretação. São Paulo: Senac, 2016.

NEGEF. Caderno de Turismo: apoio à orientação da atividade turística no Estado do Rio de Janeiro. In: MARAFON, Glaucio José; RIBEIRO, Miguel Angelo (orgs.). Revisitando o Território Fluminense III. Rio de Janeiro: Gramma, 2010. P.9-24.

NUNES, Nathan da Silva. Transformações nas dinâmicas populacional e econômica a partir dos impactos dos royalties petrolíferos no município de Casimiro de Abreu-RJ. 2015. 56f. Monografia (Graduação em Geografia - IGEOG/UERJ). Rio de Janeiro, 2015.

NUNES, Nathan da Silva. Imagem e representações nos cartões postais: a paisagem dos municípios de Armação dos Búzios, Casimiro de Abreu e Saquarema, na região das Baixadas Litorâneas. 2017. 109f. Dissertação (Mestrado em Geografia - PPGEO/UERJ). Rio de Janeiro, 2017.

NUNES, Nathan da Silva; RIBEIRO, Miguel Angelo. A dimensão espacial da atividade turística no território fluminense. In: MARAFON, Glaucio José; ARIAS, Lilliam Quirós; SÁNCHEZ, Meylin Alvarado (orgs.). Estudos territoriais no Brasil e na Costa Rica. Rio de Janeiro: EdUERJ, 2018. P.113-135.

RAHY, Ione Salomão. Povoamento do Estado do Rio de Janeiro. In: GEOUERJ. Departamento de Geografia, UERJ, Rio de Janeiro, no. 6 , 1999. P.. 37-43.

RIBEIRO, Miguel Angelo. Considerações sobre o espaço fluminense: estrutura e transformações. Departamento de Geografia: UERJ, (mimeo), 2001.

RIBEIRO, Miguel Angelo. Turismo no Estado do Rio de Janeiro: ensaio de uma tipologia. In: GEOgraphia. Ano V. №10. 2003. p.79-91.

RIBEIRO, Miguel Angelo. Categorias Analíticas do Espaço e Turismo: o exemplo da Fortaleza de Santa Cruz, Niterói/RJ. In: GEOgraphia, Revista da Pós-Graduação em Geografia da UFF. Ano VIII, no 16, 2006, pp. 83 - 98.

SILVA, Gustavo Junger da. O turismo histórico como vetor de desenvolvimento sócio-econômico em Paraty: estratégias, limitações e reflexos no urbano. In: In: MARAFON, Glaucio José; RIBEIRO, Miguel Angelo (orgs.). Revisitando o Território Fluminense II. Rio de Janeiro: Gramma, 2008. P.263-286. 